\title{
PERCEPCJA EUROPY \\ W WYSTĄPIENIACH PREZYDENTA REPUBLIKI CHORWACJI FRANJA TUDJMANA (1991-1999)
}

\author{
JĘDRZEJ PASZKIEWICZ
}

\begin{abstract}
Perception of Europe in the speeches by the President of Republic of Croatia Franjo Tudjman (1991-1999).

The article deals with the discursive process through which Croatia framed its so-called "return to Europe" throughout the 1990s. The author explores how Franjo Tudjman perceived Europe and European values by defining Croatian national identity in the strict opposition to the Balkan or Yugoslav identity. The post-communist government, which came to power after the first democratic elections in 1990, made use of the pre-communist historical-national narratives to legitimize itself and unify all ethnic Croats against the military threat. Even though since the beginning of the 1990s the Croatian president had declared his desire to join the European Union (EU) as a visible symbol of the so called Europeanization process, a nationalist and isolationist attitude dominated both his political discourse and the intellectual debate. Europe was associated with the ontological values dedicated to the Western civilization rather than with such principles as democratization or the protection of human and minority rights, promoted by the EU. In order to show the main directions within the F. Tudjman's discourse, I used the analysis method focusing on his speeches and other works.
\end{abstract}

Autor: Jędrzej Paszkiewicz, Uniwersytet im. Adama Mickiewicza, Wydział Historyczny, Instytut Historii, ul. Umultowska 89D, 61-614 Poznań, prosinac@amu.edu.pl

Slowa kluczowe: Chorwacja; Tudjman; Bałkany; Unia Europejska

Keywords: Croatia; Tudjman; Balkans; European Union

Balcanica Posnaniensia. Acta et studia, XXII/2, Poznań 2015, Wydawnictwo Instytutu Historii UAM, pp. 171-186, ISBN 978-83-63047-88-7, ISSN 0239-4278. Polish text with a summary in English.

Wizja Europy, obecna w chorwackim życiu politycznym lat 90. XX wieku, w zasadniczej części nawiązywała do wypowiedzi i publikacji autorstwa prezydenta Republiki Chorwacji Franja Tudjmana. W omawianym okresie polityk ten, uznawany przez wielu rodaków w kraju i zagranicą za „ojca chorwackiej państwowości”, wykorzystywał autorytet, zdobyty w okresie walki politycznej i zbrojnej o niezależność Chorwatów, aby wpływać na poglądy społeczeństwa i umacniać rządy swojego obozu politycznego, związanego z Chorwacką Wspólnotą Demokratyczną (Hrvatska demokratka zajednica; HDZ) ${ }^{1}$. Bez wątpienia, działalność F. Tudjmana, wyrażająca się publikacjami naukowymi i licznymi wystąpieniami publicznymi, miała wielki wpływ

${ }^{1}$ M. Belaj, N. Škrbić Alempijević, Remembering "The Father of the contemporary state of Croatia. The celebration of Tuđman's birthday in his birthplace, "Traditiones", t. 43, nr (1), 2014, s. 86-89; J. Sadkovich, Franjo Tuđman: An Intellectual in politics, w: S. P. Ramet, K. Clewing R. Lukić (red.), 
na całokształt chorwackiego dyskursu społecznego. Postać pierwszego prezydenta Republiki Chorwacji była powszechnie utożsamiana z „odzyskaniem” niepodległości przez Chorwatów, przypisywano jej także wielkie zasługi w dziele budowania jedności narodowej. Ważkim elementem jego myśli politycznej był rozwijany od lat 70. XX wieku koncept ,pojednania” Chorwatów, podzielonych w ocenach wydarzeń z czasów II wojny światowej, gdy na ziemiach chorwackich walczyły ze sobą partyzantka komunistyczna i skrajnie prawicowy reżim ustaszy, współpracujący z faszystowskimi Włochami i Trzecią Rzeszą. Rezultatem działań F. Tudjmana było stworzenie w 1989 roku HDZ, określanej przez jej lidera mianem ogólnonarodowej platformy politycznej. Miała ona wyrażać interesy całego narodu chorwackiego w realiach rozpadu struktur federacji jugosłowiańskiej i narastania nacjonalizmu serbskiego, który w ocenie lidera ruchu poważnie zagrażał Chorwatom ${ }^{2}$. F. Tudjman jest również uznawany za współtwórcę naukowej i politycznej konceptualizacji dziejów narodu chorwackiego, w której zrelatywizowano odbiór tradycji komunistycznej i ustaszowskiej przywołano na nowo przywołano najważniejsze mity narodowe i religijne. Działania te wspierały ideę chorwackiej odrębności i niepodległości w czasach jugosłowiańskich oraz legły u podstaw ideologii niezależnej Republiki Chorwacji ${ }^{3}$.

Integralną część dorobku naukowego F. Tudjmana, rozwijanego od końca lat 60. XX wieku, stanowią rozważania o europejskiej identyfikacji kulturowej, historycznej i geopolitycznej Chorwatów. W swoich książkach podkreślał on, że szczególny wpływ na kreowanie dziejów Europy i tworzenie jej charakterystyki duchowej mają żywioły narodowe. W tym właśnie kontekście F. Tudjman lokował i wyjaśniał skomplikowane dzieje narodu chorwackiego. Przybliżał procesy historyczne, postaci i wydarzenia, które wywarły szczególny wpływ na charakterystykę kulturowo-historyczną Chorwatów i świadczyły jego zdaniem o ich łączności z dokonaniami cywilizacji europejskiej. Za naturalne środowisko, w którym chorwacki żywioł narodowy dojrzewał do pełnej niezależności, prezydent uznawał Europę środkową, opartą na dziedzictwie średniowiecznego Królestwa Węgierskiego i monarchii habsburskiej ${ }^{4}$.

W przekazie na temat Europy, konkretyzowanym na podstawie wypowiedzi F. Tudjmana, dostrzec można wyraźną ewolucję percepcji tego terminu. Jest ona ściśle powiązana z charakterystyką ówczesnej sytuacji geopolitycznej i wewnętrznej Chorwacji. W pierwszej połowie lat 90 ., w wystąpieniach prezydenta, jak i innych chorwackich polityków związanych z jego obozem politycznym, dominuje przekaz pozytywny, bazujący na przekonaniu, że Republika Chorwacji stanowi integralną

Croatia since Independence: war, politics, society, foreign relations, R. Oldenbourg Verlag, München, 2008, s. 59-85; idem, Tuđman: prva politička biografija, Večernji posebni proizvodi, Zagreb, 2010.

${ }^{2}$ Hrvatska riječ svijetu. Razgovori sa stranim predstavcima, A. Mijatović (red.), Svjedoci povijesti, Zagreb, 1999, s. 73.

${ }^{3}$ S. Đurasković, Nation-building in Franjo Tuđman's political writings, "Croatian Political Science Review, t. 51, nr 5, 2014, s. 59; D. Agičić, Historiografia chorwacka w latach 1990-2010. Struktura i główne kierunki rozwoju, „Prace Komisji Środkowoeuropejskiej PAU”, t. 20, 2012, s. 65.

${ }^{4}$ Bibliografia prac F. Tudjmana w: idem, Velike ideje i mali narodi. Razprave i ogledi, Matica hrvatska, Zagreb 1996, s. 332-333. 
część wspólnoty narodów europejskich. Budowany jest generalnie pozytywny obraz procesu integracji europejskiej ${ }^{5}$. W połowie tego okresu do silniejszego głosu dochodzą jednak wątki o wydźwięku antyeuropejskim. Jest to czas, gdy władze chorwackie dystansują się wobec polityki Unii Europejskiej, co powoduje wzajemną nieufność i ograniczenie współpracy z instytucjami międzynarodowymi, choćby w sprawach dotyczących odpowiedzialności karnej chorwackich obywateli za zbrodnie wojenne z pierwszej połowy dekady. Także ówczesne inicjatywy o wymiarze integracyjnym, formułowane przez Wspólnotę Europejską, były odbierane przez elity rządzące w Chorwacji z krytycyzmem, a nawet wrogością. Uznawano je za zagrożenie dla chorwackiej racji stanu, opierającej się na postulacie pełnej niezależności państwowej Chorwacji. Politycy unijni (europejscy) byli również krytykowani za to, że nadal rozpatrywali Chorwację w kontekście bałkańskich odniesień geopolitycznych, co w opinii chorwackich elit rządzących miało zaprzeczać europejskiej tożsamości Chorwatów ${ }^{6}$.

\section{CHORWACJA MIĘDZY RODZINNĄ EUROPA A BARBARZYŃSKIMI BAŁKANAMI}

W oficjalnym chorwackim dyskursie, pozytywny i afirmacyjny odbiór Europy, postrzeganej jako świat cywilizowanych, utwierdzonych przez wieki wartości porządkujących relacje społeczne i polityczne, łączył się z niechęcią wobec tego, co bałkańskie. Bałkany były utożsamiane $\mathrm{z}$ autorytarną bądź totalitarną władzą, a także z bezładem cywilizacyjnym i ekonomicznym ${ }^{7}$. Posługując się tymi zestawieniami, chorwaccy decydenci wielokrotnie podkreślali, że na początku lat 90. Chorwaci powracali po Europy jako pełnoprawny podmiot, po kilkudziesięcioletnim okresie wymuszonego funkcjonowania na Bałkanach, to znaczy w Jugosławii. Bez wątpienia, idea powrotu Chorwatów na łono europejskiej wspólnoty cywilizacyjnej korespondowała z hasłami o podobnym wydźwięku, które były formułowane w prawie całej postkomunistycznej części kontynentu. Powszechnie przecież zakładano, że transformacja systemowa, porównywana z drogą tamtejszych państw i społeczeństw ku współczesnej Europie, powinna bazować na wartościach i doświadczeniach wyniesionych ze

\footnotetext{
${ }^{5}$ Por. Franjo Tuđman. Govor prilikom konstituirajuće sjednice Hrvatskoga Sabora; 30.05.1990; http://www.tudjman.hr/govori/konstituirajuca-sjednica-hrvatskoga-sabora [dostęp: 20.10.2015].

${ }^{6}$ J. Sadkovich, Franjo Tuđman i problem stvaranja hrvatske države, "Časopis za suvremenu povijest" br. 1., 2008, s. 179-180.

${ }^{7}$ M. Razsa, N. Lindstrom, Balkan is beautiful: Balkanism in the political discourse of Tudman's Croatia, "East European Politics and Societies", t. 18, nr 4, 2004, s. 630; B. Skoko, Percepcija Europske Unije u hrvatskoj javnosti, „Anali hrvatskog politološkog društva”, t. 3, nr 1, 2006, s. 354. Kompetentnie o percepcji zestawienia Europa-Bałkany, obecnego w chorwackim dyskursie społeczno-politycznym pisze Z. Czerwiński, Chorwacja między Europa a Bałkanami. Analiza dyskursu prasowego, w: $W$ poszukiwaniu nowego kanonu, Reinterpretacje tradycji kulturalnej w krajach postjugostowiańskich po 1995 roku, M. Dąbrowska-Partyka (red.), Wydawnictwo Uniwersytetu Jagiellońskiego, Kraków, 2005, s. 97-117.
} 
stabilnych demokracji wolnorynkowych w wydaniu zachodnioeuropejskim ${ }^{8}$. Można jednak odnieść wrażenie, że usytuowanie Chorwacji w niestabilnym politycznie rejonie, na styku Europy środkowej, śródziemnomorskiej i Bałkanów, zaważyło na stworzeniu szczególnej atmosfery niepewności. W Chorwacji nieustannie zadawano sobie pytanie, jakie miejsce zostanie wyznaczone nowo powstałemu państwu na tzw. „mentalnej mapie Europy" ". Zwracano uwagę, że opinie na temat tego, którędy przebiegają cywilizacyjne granice kontynentu nie stronią od stereotypów i przesądów głęboko zakorzenionych w ludzkiej świadomości ${ }^{10}$. Obawa, że Chorwaci mogli zostać sklasyfikowani jako naród bałkański, budziła duże zaniepokojenie. Z pewnością pobudzało to elity rządzące do nieustannego podkreślania swojej bezkompromisowej europejskości, zarówno w kraju, jak i za granicą.

Europejską tożsamość Chorwatów budowano na podstawie przekonania, że należą oni do rodziny „,najstarszych narodów europejskich”, a ewolucja ich życia narodowego i państwowego przebiegała w tym samym tempie, co procesy państwowotwórcze w najbardziej zaawansowanych cywilizacyjnie częściach kontynentu. F. Tudjman podkreślał w licznych wypowiedziach, że Chorwacja stała niezależnym bytem państwowym już podczas „ery bizantyńsko-frankijskiej”, a więc między 9 a 12 wiekiem n.e. Co prawda, w czasach unii państwowej z Węgrami i Austrią Chorwacja utrzymała swój byt państwowy w ograniczonym zakresie, ale nawet w tak zawężonych ramach prężnie rozwijał się ,indywidualny charakter narodowy" Chorwatów ${ }^{11}$. Chorwacki historyk i polityk podkreślał, że węgierscy królowie byli jednocześnie władcami Królestwa Chorwacji, w skład którego wchodziły także Slawonia i Dalmacja, ważne krainy historyczne współtworzące terytorium dzisiejszej Republiki. Pozytywnie oceniał on także historyczną rolę monarchii habsburskiej, mimo że kwestia odrębności politycznej Chorwatów w tych czasach wielokrotnie była przedmiotem kontrowersji politycznych. W przekonaniu F. Tudjmana jednak, monarchia habsburska zdołała wykreować coś, co określał on mianem „naturalnej całości”, obejmującej ziemie i narody o bardzo zróżnicowanej charakterystyce ekonomicznej oraz kulturowej. Co więcej, w odniesieniu do dziedzictwa habsburskiego można było mówić o istnieniu swoistego pokrewieństwa kulturowego między ludami zasiedlającymi cały obszar Europy środkowej. W tym kontekście okres jugosłowiański, rozpięty między 1918 a 1991 rokiem, zwykle jest przedstawiany w wystąpieniach prezydenta jako czas wyrwania Chorwatów ze środkowoeuropejskiego obiegu kulturowego oraz nasi-

\footnotetext{
${ }^{8}$ M. Petrovic, The democratic transition of post-communist Europe: in the shadow of communist differences and uneven EUropeanisation, Houndmills, New York 2013, s. 108-113.

${ }^{9}$ P. Novosel, Europa 1992 i Hrvatska 1991,, w: Novinarstvo i Europa 92, M. Plenković (red.), Alinea, Zagreb, 1991, s. 26.

${ }^{10}$ Izvješće Predsjednika Republike Hrvatske Dr. Franje Tuđmana o stanju hrvatske države i nacije u 1996. godni, 22.01.1997; http://www.tudjman.hr/govori/ [dostęp: 16.10.2015].

${ }^{11}$ Prisežna poslanica Predsjednika Republike Hrvatske dr. Franje Tuđmana; 05.08.1997; http:// www.tudjman.hr/govori/prisezna-poslanica-1997 [dostęp: 18.10.2015]; idem, On historical necessity and contradictions between sovereignty and integration of European nations, „National security and the future", t. 3-4, nr 1, 2000, s. 147-148.
} 
lenia nacisków zmierzających do zniszczenia chorwackiej tożsamości narodowej. Jak to ujął F. Tudjman, w warunkach porządku wersalskiego, a także w następstwie decyzji niektórych chorwackich kół politycznych, Chorwaci znaleźli się w państwie, które stanowiło przedmiot ,serbskich nacisków hegemonistycznych”. Wobec zagrożenia ze strony serbskiego nacjonalizmu, część Chorwatów poparła postulat niezależności narodowej podczas drugiej wojny światowej, ogłaszając niepodległość państwową w ramach, jak to określał F. Tudjman, nowego „hitlerowskiego porządku europejskie-

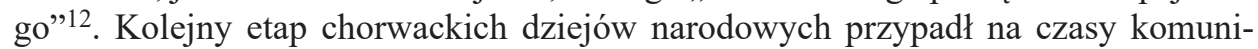
styczne, gdy w ramach komunistycznej Federacyjnej Republiki Jugosławii stworzono Socjalistyczną Republikę Chorwacji. Formuła ponadnarodowej federacji, odwołującej się do ducha komunistycznego internacjonalizmu, nie wytrzymała jednak próby czasu. Ustąpiła pod presją narodów, które aspirowały do politycznej suwerenności i niezależności ${ }^{13}$.

\section{CHORWACKA SUWERENNOŚĆ NARODOWA I PAŃSTWOWA W OBLICZU PROCESÓW INTEGRACYJNYCH W EUROPIE}

Znaczące zmiany w chorwackiej retoryce na temat Europy, rozwijanej przez władze, nastąpiły w połowie lat 90 . XX wieku, wraz z zakończeniem działań wojennych na terenie Chorwacji. Przed rządzącymi stawiano wówczas wiele trudnych zadań. Wśród najważniejszych F. Tudjman wymieniał konsolidację terytorialną państwa, jego odbudowę ze zniszczeń wojennych i umocnienie bezpieczeństwa narodowego. HDZ podkreślała konieczność utrzymania mobilizacji narodowej społeczeństwa wobec wszelkich przejawów zagrożenia państwa ${ }^{14}$. Stanowisko to przekładało się na niechętny stosunek rządzących wobec mniejszości etniczno-narodowych i działań promujących dialog z państwami regionu. Chorwacja dystansowała się wobec koncepcji współpracy regionalnej, choć zdawano sobie sprawę, że był to warunek sine qua non rozpoczęcia rozmów o członkostwie w NATO i UE ${ }^{15}$. Ta ówczesna rezerwa Chorwacji wobec środowiska międzynarodowego korespondowała z krytycznym stanowiskiem zagranicy. Władzom chorwackim zarzucano łamanie wolności słowa, upolitycznienie aparatu państwowego, utwierdzanie kryminogennych powiązań między polityką a biznesem ${ }^{16}$.

12 Ibidem, s. 148; por. A. Bing, Samoodreðenje naroda i koncepcije hrvatske državnosti u kontekstu Drugog svjetskog rata - refleksije povijesnog kontinuiteta, „Radovi. Zavod za hrvatsku povijest”, t. 45, 2013, s. 133 .

13 F. Tuðman, Velike ideje i mali narodi, s. 346.

14 Izvješće Predsjednika Republike Hrvatske Dr. Franje Tuđmana o stanju hrvatske države i nacije u 1995. godni, 15.01.1996; http://www.tudjman.hr/govori/ [dostęp: 16.10.2015].

15 F. Tuđman, Izlaganje prilikom sedme obljetnice Prvog sabora HDZ-a; 23.02.1997; http://www.tudjman.hr/izlaganje-prilikom-sedme-obljetnice-prvog-sabora-hdz-a-1997 [dostęp: 17.10.2015].

16 D. Jovic, Ch. Lamont, Croatia after Tuđman: encounters with the consequences of conflict and authoritarianism, "Europe-Asia studies", t. 62, nr 10, 2010, s. 1612-1614. W literaturze naukowej okres ten 
W tym właśnie okresie percepcja Europy w chorwackim dyskursie społeczno-politycznym rozwarstwia się na dwa kontrastujące ze sobą przekazy. Pierwszy, o charakterze afirmatywnym, odnosi się do niekwestionowanego powinowactwa między narodowością chorwacką a dziedzictwem środkowoeuropejskiej przestrzeni geopolitycznej. Wynika z niego postulat jak najszybszego wejścia Chorwacji do struktur euroatlantyckich, wraz z innymi państwami regionu, które w tym okresie podjęły działania w kierunku integracji z Paktem Północnoatlantyckim i Unią Europejską. Z kolei drugi przekaz jest formułowany w oparciu o krytyczną obserwację ówczesnych stosunków międzynarodowych, gdy skomplikowały się relacje polityczne między tudjmanowską Chorwacją a poszczególnymi państwami zachodnioeuropejskimi ${ }^{17}$. Największe sprzeczności dotyczyły poglądów na kształt ładu międzynarodowego w tzw. strefie postjugosłowiańskiej. Zdaniem F. Tudjmana., działania podejmowane przez unijnych polityków w zasadzie zmierzały do odtworzenia stosunków znanych Chorwatom z czasów socjalistycznej Jugosławii i miały na celu zanegowanie suwerenności miejscowych narodów. W jego opinii, mocarstwa europejskie starały się izolować Chorwację na arenie międzynarodowej. Marginalizowały jej rolę, chcąc skłonić do porzucenia niepodległości i przyjęcia koncepcji obliczonych na ponowną integrację polityczną oraz ekonomiczną republik postjugosłowiańskich ${ }^{18}$.

Rozważania o sprzeczności występującej między suwerennością narodów europejskich a zagadnieniem ich integracji zajmowały bardzo ważne miejsce w myśli naukowej oraz politycznej Franja Tudjmana. W jego przekonaniu, istotą nowego ładu międzynarodowego w Europie, opartego na demokratyzacji i transformacji systemowej państw postkomunistycznych, musiało być poszanowanie prawa każdego bytu narodowego do samostanowienia. W szczególności powinno to dotyczyć narodów, które w swoich rozważaniach naukowych F. Tudjman nazywał „mniejszymi i słabszymi”. Jego zdaniem, przetrwanie wielu takich wspólnot, które w przeszłości często były zmuszane do funkcjonowania w strukturach ponadnarodowych, było nadal zagrożone ze względu na naciski ze strony silniejszych narodów. Chorwacki prezydent podkreślał, że unijni kreatorzy procesów nastawionych na integrację współczesnej Europy powinni uważnie przestudiować doświadczenia tych, którzy w XX wieku nie mieli możliwości pełnego wyrażenia swoich suwerennych praw ${ }^{19}$.

Według słów F. Tudjmana, historia pokazuje, że idee o wymiarze uniwersalnym, głoszące postulaty równorzędności i podmiotowości wszystkich narodów lub grup

nazywany jest niekiedy czasem „deficytu demokracji”, gdy środowisko związane z HDZ i prezydentem F. Tudjmanem przejęło kontrolę nad instytucjami państwa, wykorzystując je do utwierdzenia swojej przewagi wobec opozycji; D. Lalović, O totalitarnim značajkama hrvatske države (1990.-1999.), „Politička misao", t. 37, nr 1, 2000, s. 188-204.

${ }^{17}$ B. Klepač Pogrmilović, Evaluating Tuđman ’s foreign policy. (Un) successful protection of national interest; from defender to despot,"Međunarodne studije", t. 13, nr 3-4, 2013, s. 62-63.

${ }^{18}$ Izvješće Predsjednika Republike Hrvatske Dr. Franje Tuđmana o stanju hrvatske države i nacije u 1996. godini, s. 8; D. Jovic, Croatia and the European Union: a long delayed journey, "Journal of Southern Europe and the Balkans", t. 8, nr 1, 2006, s. 90.

${ }^{19}$ F. Tuðman, On historical necessity, s. 150. 
społecznych zawsze będą wykorzystywane przez państwa lub narody dominujące do przejęcia kontroli nad słabszymi, do narzucenia im własnych rozwiązań politycznoterytorialnych. W tym przypadku idealistyczne cele i hasła zwykle ustępują miejsca interesom narodowym ${ }^{20}$. F. Tudjman wielokrotnie przywoływał przykład socjalistycznej Jugosławii, która choć oparta na zasadzie komunistycznego internacjonalizmu rozpadła się pod presją partykularyzmów narodowych. Jego zdaniem, federacja, której przywódcy głosili hasła równouprawnienia wszystkich narodów jugosłowiańskich, w istocie sankcjonowała ich nierównorzędność w stosunkach wewnętrznych, ponieważ została zdominowana przez serbski partykularyzm narodowy. Strona serbska systematycznie wzmacniała swoją pozycję w strukturach państwowych i partii rządzącej, rozwijając ekspansję narodową kosztem pozostałych członów federacji. F. Tudjman uważał, że „środowisko serbskie” w zasadzie nigdy nie zaakceptowało idei federacyjnej równorzędności narodów południowosłowiańskich, leżącej u podstaw komunistycznego ruchu oporu z czasów II wojny światowej. Od pierwszych lat federacji zmierzało do jej zdominowania i przekształcenia w myśl serbskiego nacjonalizmu. W opinii F. Tudjmana, Serbowie osiągali wiele korzyści w związku z trwaniem federacji, podczas gdy inne narody, zwłaszcza Chorwaci i Słoweńcy, były w niej marginalizowane. W następstwie tych doświadczeń, jugosłowiańska idea integracyjna poniosła klęskę. Aby przetrwać, Chorwaci musieli skoncentrować się na walce o stworzenie własnego państwa narodowego ${ }^{21}$.

Rozważania F. Tudjmana na temat przyczyn upadku socjalistycznej Jugosławii legły u podstaw krytyki postulatów, zakładających kreowanie ponadnarodowej Europy jako podstawy dla jednolitego narodu europejskiego, pojawiających się w wypowiedziach unijnych polityków w latach 90. XX weku. W swoich wystąpieniach Prezydent Chorwacji podkreślał, że żadna siła w historii nie była i nie będzie zdolna „sztucznie” stworzyć nowego narodu na podstawie tych istniejących. Jak zaznaczał, tylko narody powstają i rozwijają się w sposób naturalny, w ramach obiektywnych i długotrwałych procesów historycznych. Są ,rezultatem rozwoju sił materialnych i duchowych”, które rozwijają się w określonej, swoistej przestrzeni ${ }^{22}$. Każda inna wspólnota, tworzona na gruncie koncepcji forsowanych przez mocarstwa lub sojusze ideologiczne jest krótkotrwała i znika wraz ze zmianą układu stosunków międzynarodowych. Stabilne podstawy dla rozwoju organizacji państwowej daje wyłącznie byt narodowy, który nie powinien być porzucany w imię wyższych interesów i celów. W opinii F. Tudjmana, im bardziej współczesna cywilizacja będzie się globalizować, a świat integrować ekonomicznie, tym bardziej tożsamości narodowe będą wpływać na charakterystykę relacji międzyludzkich. Jak przekonywał F. Tudjman, „współczesne doświadczenie uczy, że im bardziej świat staje się zintegrowany technologicznie, tym bardziej uwidaczniają są cechy różnicujące narody pod względem ich charakteru oraz

${ }^{20}$ Idem, Velike idee i mali narodi, s. 23.

${ }^{21}$ D. Jovic, Croatia and the European Union, s. 92.

${ }^{22}$ Govor na zasjedanju Opće skupštine Ujedinjenih naroda; 28.09.1993; http://www.tudjman.hr/ govori/zasjedanje-opce-skupstine-ujedinjenih-naroda [dostęp: 18.10.2015]. 
interesów". To, co się wydarzyło pod koniec XX wieku w Jugosławii powinno, jego zdaniem, uzmysłowić architektom postzimnowojennego porządku europejskiego, że koncept ponadnarodowej Europy jest błędny, a polityczne jednoczenie kontynentu powinno przebiegać w inny sposób ${ }^{23}$.

F. Tudjman zwracał uwagę na to, że w obliczu zmian politycznych, jakie zaszły w Europie na początku lat 90. XX powinna się ona wyzwolić spod - jak to określał - „imperialistycznych i hegemonistycznych ciężarów przeszłości”. W szczególności należało porzucić chęć integrowania narodów na siłę, pod dyktat odgórnie narzuconych postulatów ideologicznych. Zdaniem F. Tudjmana, rzeczywistość „nowej Europy" powinny tworzyć takie wartości, jak pokojowe współistnienie, pluralizm idei i policentryczność systemów społecznych oraz państwowych. Proces integracji powinien być prowadzony stopniowo, w oparciu o zasadę dobrowolności, przy poszanowaniu wolnej woli i interesów poszczególnych państw ${ }^{24}$. W tym kontekście F. Tudjman wyrażał poparcie dla koncepcji stworzenia Zjednoczonych Stanów Europy, forsowanej przez część środowisk politycznych UE, choćby we Francji czy Wielkiej Brytanii. Formułę tę uznawał on za najbezpieczniejszą także i z punktu widzenia chorwackich interesów narodowych. W jego ocenie, warunkiem sukcesu idei integracyjnej była ochrona niezależności mniejszych, słabszych państw przed naciskami ze strony mocarstw współkreujących politykę ogólnoeuropejską ${ }^{25}$.

\section{AROGANCKA EUROPA I SAMOWYSTARCZALNA CHORWACJA}

Działania środowiska związanego z prezydentem F. Tudjmanem oraz HDZ, podejmowane w latach 90. XX wieku, przyczyniły się do ugruntowania niepodległości Republiki oraz jej integralności. Z drugiej strony, nacjonalistyczna polityka, podkreślająca narodowy charakter państwa, systematycznie pogłębiała jego alienację wobec spraw europejskich. Duży wpływ na umacnianie się wśród Chorwatów poczucia osamotnienia wobec Europy, miało krytyczne nastawienie do działalności Międzynarodowego Trybunału do spraw zbrodni wojennych popełnionych na terenie byłej Jugosławii (ICTY), którego kompetencje objęły także Chorwatów. Trybunał rozpatrywał oskarżenia przeciwko oficerom, którzy w Chorwacji byli uznawani za bohaterów narodowych. Prasa donosiła o możliwości postawienia przed sądem międzynarodowym samego F. Tudjmana ${ }^{26}$. Pod presją międzynarodową, w 1996 roku władze chorwackie musiały zaakceptować to, że jej obywatele byli sądzeni przez międzynarodowe organa sądowe. W wypowiedziach z tego czasu F. Tudjman wyrażał opinię, że polityka państw zachodnieuropejskich i UE, które wspierały poczynania ICTY, miała na celu odebranie Chorwatom tego, co stanowiło podporę ich tożsamości - dumy

\footnotetext{
23 Idem, On historical necessity, s. 149.

${ }^{24}$ Ibidem, s. 150.

25 D. Jovic, Croatia and the European Union, s. 93.

${ }^{26}$ W. Bartlett, Croatia: between Europe and the Balkans,, Routledge, London, 2002, s. 63.
} 
z obrony swojego państwa przed wielkoserbskim hegemonizmem ${ }^{27}$. Stosunki wzajemne jeszcze bardziej skomplikowały się w kwietniu 1997 roku, po ogłoszeniu przez Brukselę Regional Approach Policy for countries of Western Balkans. Była to koncepcja zakładająca prowadzenie przez Wspólnotę w miarę spójnej polityki wobec państw tworzących subregion o nazwie Bałkany Zachodnie. Uwzględnienie Chorwacji w tej samej grupie co inne republiki postjugosłowiańskie (bez Słowenii) i Albania, wywołało trzęsienie polityczne w Zagrzebiu. Rozwiązanie to było ostro krytykowane zwłaszcza przez te środowiska, które swoją pozycję polityczną oparły na hasłach przywrócenia Chorwacji Europie ${ }^{28}$. Z kolei opozycyjni komentatorzy zwracali uwagę, że radykalny nacjonalizm F. Tudjmana doprowadził do wyjścia Chorwatów z socjalistycznej Jugosławii, ale i skazywał ich na nieustanne porównania z bałkańską rzeczywistością, z którą korespondowały chociażby autokratyczne zapędy prezydenta. W rezultacie, zamiast rozpoczynać wraz z innymi państwami środkowoeuropejskimi drogę ku Unii Europejskiej, Chorwacja „tkwiła” na Bałkanach, które były przez nią traktowane z lekceważeniem, a nawet pogardą. Poczynania UE były odczytywane jako cios wymierzony w propagandę obozu HDZ, która nadal przekonywała Chorwatów, że z geopolitycznego punktu widzenia powinni oni jak najszybciej znaleźć się wśród narodów przygotowujących się do członkostwa we Wspólnocie ${ }^{29}$.

W wystąpieniach z połowy lat 90., F. Tudjman zdecydowanie występował przeciwko koncepcji Bałkanów zachodnich uważając, że była ona wymierzona w żywotne interesy Chorwatów. Przestrzegał on, że uwzględnienie Chorwacji w tej samej grupie państw co Jugosławia (wówczas współtworzona przez Serbię i Czarnogórę) zostanie odebrane przez skrajne środowiska nacjonalistyczne w Serbii jako przyzwolenie do aktywizacji działań politycznych i zbrojnych, wymierzonych w integralność państwa chorwackiego. Co więcej, w jego wystąpieniach przywoływane są sugestie, że kręgi polityczne z Europy zachodniej chciały osłabić patriotyczną mobilizację chorwackiego społeczeństwa, wspierając działalność opozycji politycznej i organizacji pozarządowych. W opinii prezydenta, pod kuratelą międzynarodową tworzono „,front” złożony $\mathrm{z}$ antynarodowo nastawionych polityków, popierających koncepcję integracji regionalnej na Bałkanach ${ }^{30}$. Pod wpływem obaw, że w obliczu zsynchronizowanych

${ }^{27}$ Moramo razvijati svijest da o nama samima ovisi naša sudbina; Intervju za list MI, 1998. godine; http://www.tudjman.hr/intervju-za-list-mi-1998-godine [dostęp: 18.10.2015]; V. Peskin, International justice in Rwanda and the Balkans. Virtual trials and the struggle for state cooperation, Cambridge University Press, Cambridge, 2008, s. 92-93, 99; Victor Peskin, Mieczysław P. Boduszynski, International justice and domestic politics: post-Tudjman Croatia and the International Criminal Tribunal for the Former Yugoslavia, "Europe-Asia Studies", t. 55, nr 7, 2003, s. 1117.

28 Por. Izvješće Predsjednika Republike Hrvatske Dr. Franje Tuđmana o stanju hrvatske države i nacije u 1996. godni, s. 9; Hrvatska riječ svijetu, s. 463-464; S. Fisher, Political change in post-Communist Slovakia and Croatia: From nationalist to Europeanist, Palgrave Macmillan, New York, 2006, s. 192.

29 B. Klepač Pogrmilović, Evaluating Tuđman's foreign policy, s. 62-63; J. Sadkovich, Forging Consensus: How Franjo Tuđman became an authoritarian nationalist, "Review of Croatian History", t. 6, nr 1, 2010, s. 22-23.

${ }^{30}$ Izlaganje prilikom sedme obljetnice Prvog sabora HDZ-a; 23.02.1997; A. Bing, Hrvatska u međunarodnoj zajednici, w: Stvaranje hrvatske države i Domovinski rat, Z. Radelić, D. Marijan, N. Barić, A. Bing, D. Živić (red.), Školska knjiga, Hrvatski institut za povijest, Zagreb 2006, s. 411. 
nacisków zewnętrznych i wewnętrznych Chorwacja będzie wręcz zmuszona zrzec się swojej podmiotowości międzynarodowej, roku chorwacki parlament znowelizował w 1997 roku artykuł 141 Konstytucji. Zabroniono w nim inicjowania procesu mogącego doprowadzić do stowarzyszenia Republiki z innymi państwami, jeśli mogło to spowodować „odtworzenie jugosłowiańskiej wspólnoty państwowej lub stworzenia nowej unii na Bałkanach, w jakiejkolwiek formie"31.

Jak argumentował F. Tudjman, Europa zapomniała, że w sensie historycznym Bałkany stanowiły w chorwackiej przeszłości zaledwie „epizod”, w przeciwieństwie do długotrwałego uczestnictwa Chorwatów w sprawach kształtujących cywilizację Zachodu. W tym samym roku, podczas kampanii przed wyborami prezydenckimi, F. Tudjman walczył o elektorat pod hasłem „Tudjman, a ne Balkan”. Kandydat wskazywał, że jego zasługi w dziele budowy niepodległego państwa stanowiły największą gwarancję ostatecznego odseparowania Chorwacji od skojarzeń z Bałkanami ${ }^{32}$. W wystąpieniach chorwackiego prezydenta z drugiej połowy lat 90. XX wieku często przywoływane są również oskarżenia tzw. Zachodu, w tym również najsilniejszych państw Unii Europejskiej, że celowo umniejszały rolę Chorwatów w dziele upadku antydemokratycznej federacji. W jego opinii, Jugosławia aż do końca swego istnienia była „skarbem Zachodu oraz obiecującym projektem” politycznym, stawianym za przykład mniejszym narodom, które aspirowały do niezależności. Zachód miał faworyzować politykę federacji nawet wtedy, gdy pogrążała się w krwawej anarchii. W orędziu o stanie państwa i narodu, wygłoszonym dnia 6 grudnia 1996 roku prezydent stwierdził:

\begin{abstract}
Wszystkie siły polityczne: od Londynu, Paryża, Rzymu do Bonn i Waszyngtonu i oczywiście Moskwa, sprzyjały tak jak tylko mogły utrzymaniu byłej Jugosławii jako kamienia węgielnego porządku wersalskiego w tej części Europy. Gdy wszystkie wysiłki na rzecz uratowania Jugosławii poniosły klęskę, te same kręgi uznały, że niepodległa Chorwacja nie przetrwa, narażona na rewoltę serbskiej ludności i supremację armii jugokomunistycznej. Wszystkie mocarstwa europejskie, wraz z Unią Europejską i Ameryką, a także ONZ nie tylko pasywnie patrzyły, jak siły jugo-komunistyczne i serbskie barbarzyńsko niszczyły Vukovar i inne chorwackie miasta jesienią 1991 roku, ale i poparły embargo nałożone przez Radę Bezpieczeństwa ONZ. Oznaczało to pozostawienie bezbronnej Chorwacji na łaskę Armii Jugosłowiańskiej, która była wówczas uznawana za jedną z największych sił militarnych w Europie ${ }^{33}$.
\end{abstract}

W przekonaniu F. Tudjmana, militarny i polityczny sukces chorwackich działań niepodległościowych stanowił dla części polityków europejskich duże i niemiłe za-

31 Poslanica Predsjednika Republike Hrvatskom državnom saboru u prigodi promjene Ustava Republike Hrvatske i obilježavanja sedme obljetnice proglašenja Ustava Republike Hrvatske; 18.12.1997; http://web.archive.org/web/20130423172526/http://www.predsjednik.hr/Zagreb18.Prosinca1997 [dostęp: 18.10.2015].

32 R. Senjković, Olučni i nasmijani (vizualni aspekti političke propagande za izbora u Hrvatskoj: 1990.-1997, „Etnološka tribina”, t. 27, 1997, s. 120; N. Lindstrom, Between Europe and the Balkans: Mapping Slovenia and Croatia's "Return to Europe" in the 1990s, "Dialectical Anthropology", t. 27, 2003, s. 319-320.

33 Izvješće Predsjednika Republike Hrvatske Dr. Franje Tuđmana o stanju hrvatske države i nacije u 1996. godni, 22.01.1997; http://www.tudjman.hr/govori/ [dostęp: 16.10.2015]. 
skoczenie. Gdy okazało się, że pasywna polityka mocarstw europejskich wobec tzw. kwestii chorwackiej nie zdołała uchronić federacji przed rozpadem, mocarstwa uznały, że należało ograniczyć rozmiary i skutki zwycięstwa Chorwatów nad serbską agresją. W tym celu podjęły one działania na rzecz tworzenia różnych form kooperacji ponadnarodowej w rejonie postjugosłowiańskim. Dla F. Tudjmana pomysły te prowadziły do utworzenia czegoś w rodzaju Jugosławii bis. Zdaniem, prezydenta, naciski sił zachodnioeuropejskich na rozwijanie współpracy regionalnej na Bałkanach zachodnich były obliczone na ograniczenie nadmiernej ich zdaniem kreatywności chorwackiej polityki zagranicznej, rozwijanej przez środowisko HDZ w latach 90. XX wieku. W opinii prezydenta, Europa chciała dać chorwackim politykom swoistą nauczkę za to, że za jej plecami dogadali się ze Stanami Zjednoczonymi w sprawie pokoju daytońskiego. Według chorwackiej propagandy, aktywność dyplomatyczna i wpływy polityczne prezydenta Chorwacji walnie przyczyniły się do pacyfikacji konfliktu w Bośni i Hercegowinie. F. Tudjman przekonywał, że koncepcja pokoju daytońskiego została wypracowana w USA, w zasadzie bez współudziału strony zachodnioeuropejskiej. Tego kręgi europejskie nigdy Chorwacji nie wybaczą - uważał prezydent ${ }^{34}$.

Według propagandy HDZ, UE postępowała „nie fair” wobec Chorwacji i Chorwatów, ponieważ traktowała ich jako niewiele znaczący element na scenie międzynarodowej. Antyeuropejska retoryka, rozwijana w tym okresie przez władze, korespondowała z duchem narracji antyjugosłowiańskiej, rozwijanej od początku lat 90. Jak zwrócił uwagę politolog Dejan Jović, na określenie sił, które nie akceptowały istnienia suwerennej i podmiotowej Chorwacji, ówczesna propaganda rządowa używała wymiennie terminów Jugosławia i Europa, bądź też Belgrad i Bruksela. W tym ujęciu Europę zazwyczaj utożsamiano z Unią Europejską, która była charakteryzowana jako sztuczny byt o charakterze ponadnarodowym, wykreowany na podstawie „nierealistycznego projektu politycznego". Europa w takim rozumieniu była oceniana jednoznacznie negatywnie. Tak jak federacja jugosłowiańska stawiała ona pod znakiem zapytania najważniejsze osiągnięcia chorwackiego nacjonalizmu, a także była zagrożeniem dla konceptu państwa narodowego ${ }^{35}$.

Retoryka antyeuropejska spotkała się z dużym oddźwiękiem wśród Chorwatów, o czym świadczyły dobre wyniki wyborcze HDZ aż do końca lat 90 . Nałożyło się na to kilka okoliczności. Przede wszystkim, Chorwaci, tak jak i inne społeczeństwa postjugosłowiańskie, mieli z reguły krytyczny stosunek wobec sił międzynarodowych, dotyczący ich wpływu na proces rozpadu Jugosławii i na powojenne rozstrzygnięcia

${ }^{34}$ Intervju predsjednika Franje Tuđmana glavnim i odgovornim urednicima hrvatskih javnih glasila u Predsjedničkim dvorima; 22.10.1996; http://predsjednik.hr/Zagreb22.Listopada1996 [dostęp: 18.10.2015]. Chorwacka propaganda rządowa podkreślała, że zachowanie mocarstw europejskich wobec Chorwacji było pełne hipokryzji. W tym kontekście F. Tudjman krytykował stosunek poszczególnych kręgów politycznych z UE, dotyczący emigracji Serbów z Chorwacji, w następstwie operacji militarnych Oluja i Bljesak w 1995 roku. Jak podkreślał, niektóre państwa europejskie chciały dawać Chorwatom lekcje, jak należy traktować mniejszości. Zapomniały jednak, że same nie uznawały istnienia mniejszości na swoim terytorium; D. Jović, Croatia and the European Union, s. 93.

35 Ibidem, s. 95-96. 
polityczne w regionie. Negatywne odczucia były instrumentalizowane przez nacjonalistyczną propagandę, której celem było wyjaśnienie społeczeństwu, że alienacja międzynarodowa Chorwacji była wyrazem niezawinionej wrogości otoczenia, a nie wynikiem nieporadności władz. Tudjmanowska retoryka, dotycząca ,aroganckiej Europy” wobec małego narodu chorwackiego, który dopiero co wybił się na niepodległość, trafiała do przekonania szerokiego elektoratu. Społeczeństwo generalnie odrzucało również zasadność orzekania przez gremia międzynarodowe o winie Chorwatów za zbrodnie wojenne. Silny był sprzeciw wobec postulatu powrotu Serbów, którzy opuścili Chorwację w wyniku konfliktu zbrojnego z lat 1991-1995 ${ }^{36}$.

Obraz „antychorwackiej Europy”, który zaistniał w ówczesnych debatach publicznych, był wykorzystywany przez władze do pacyfikowania na miejscowym podwórku oskarżeń o łamanie praw człowieka i wolności wypowiedzi. Co więcej, w propagandzie nadal rozwijano mit walczącej Chorwacji, która co prawda wydobyła się na niepodległość, ale nadal była atakowana i musiała się bronić przed wrogami zewnętrznymi oraz wewnętrznymi. Przekaz akcentujący konieczność obrony niezależności państwowej, stanowił kontynuację narracji rozwijanej w czasach walki zbrojnej, nawołującej do konsolidacji społeczeństwa wokół władz i armii narodowej. Jak stwierdził 6 listopada 1996 roku F. Tudjman, Chorwacja wybiła się na niepodległość samotnie, dzięki wytrwałości Chorwatów. Samodzielnie wywalczyli oni należne im miejsce na scenie międzynarodowej. Powinni jednak pamiętać, że ich państwowość nadal jest zagrożona. Wrogowie państwa wykorzystają każde osłabienie chorwackiego ducha narodowego, rozwijanego pod skrzydłami $\mathrm{HDZ}^{37}$.

Wizja państwa pielęgnującego niezależność i tożsamość narodową w dystansie wobec wielkich potęg oraz działań unifikujących scenę międzynarodową, często pojawiała się także w prasowych wypowiedziach prezydenta. W parlamentarnym wystąpieniu z końca stycznia 1999 roku podkreślił on, że Chorwaci nie chcieli wstępować do narzucanego im procesu integracyjnego, ponieważ odrzucali rolę figuranta w stosunkach zewnętrznych ${ }^{38}$. Taka retoryka „,samowystarczalności”, pojawiająca się w wypowiedziach prezydenta na temat relacji między Chorwacją a otoczeniem międzynarodowym, jest przez niektórych badaczy zestawiana z tekstami autorstwa przywódcy jugosłowiańskiego Josipa Broz Tity. Podobieństwa dostrzegane są zwłaszcza tam, gdzie prezydent jugosłowiański rozwijał koncepcję prowadzenia przez federację polityki niezaangażowania $\mathrm{w}$ warunkach rywalizacji zimnowojennej. Zdaniem badaczy, retoryczna zbieżność między obu przywódcami jest nieprzypadkowa. Częściowo wynika z tego, że do końca lat 60 . F. Tudjman był aktywnym działaczem ruchu ko-

36 J. Paszkiewicz, Exodus Serbów z Chorwacji i główne problemy zwiąane z ich powrotem, w: Europa-Polska-migracja, S. Wojciechowski, R. Fiedler (red.), Instytut Nauk Politycznych i Dziennikarstwa UAM, Poznań 2003, s. 124.

37 J. Subotic, Europe is a state of mind: identity and Europeanization in the Balkans, "International Studies Quarterly", t. 55, 2011, s. 316.

38 Izvješće Predsjednika Republike Hrvatske dr. Franje Tuđmana o stanju hrvatske države $\boldsymbol{i}$ nacije u 1998. godini na zajedničkoj sjednici oba doma hrvatskoga državnog Sabora; http://web.archive.org/ web/20130423044549/http://www.predsjednik.hr/Zagreb20.Sijecnja1999 [dostęp: 18.10.2015]. 
munistycznego i propagatorem koncepcji jugosłowiańskiej w wydaniu internacjonalistycznym. Ponadto podobnie jak prezydent Tito, także prezydent F. Tudjman eksponował swoją szczególną rolę w konstruowaniu polityki wewnętrznej i zagranicznej oraz aktywnie umacniał swoją pierwszoplanową pozycję w państwie ${ }^{39}$.

Bez wątpienia slogan powrotu Chorwacji do Europy był jednym z najbardziej nośnych elementów propagandy władz chorwackich, prowadzonej w latach 90. XX wieku. Zgodnie z jego przesłaniem, ponowne pojawienie się Chorwatów w ogólnoeuropejskiej wspólnocie państw było momentem przełomowym w historii narodu i wielkim triumfem idei wolnościowej. Według F. Tudjmana, podczas krwawej wojny domowej z początku dekady Chorwaci wykazali, że ich dążenia były zbieżne z głęboko osadzonym w tradycji kontynentu konceptem państwa i społeczeństwa, opartych na wartościach narodowych. Europejski charakter chorwackiego życia narodowego wyrażały również takie przymioty, jak umiłowanie wolności, patriotyzm i dążenie do systematyczne rozwijanie życia narodowego. Swoje postrzeganie Europy F. Tudjman sytuował w tradycji nacjonalistycznej. Wobec Unii Europejskiej miał stosunek ambiwalentny. Z jednej strony wielokrotnie podkreślał, że przyszłość Chorwacji była we Wspólnocie współtworzącej struktury euroatlantyckie. Z drugiej strony, nie aprobował jednak wartości identyfikowanych z ideologią Unii Europejskiej, które w jego ocenie godziły w konsolidację narodową państw. Integracja europejska była przez F. Tudjmana utożsamiana z socjaldemokratyczną i liberalną wizją społeczeństwa wielokulturowego, którą odrzucał, bazując na koncepcie ekskluzywizmu narodowego. Z tego powodu, wśród zasad ważnych z punktu widzenia Unii Europejskiej, które w tudjmanowskiej Chorwacji były raczej bagatelizowane, należy wymienić postulat demokratycznych rządów prawa, wolność wypowiedzi czy ochronę praw mniejszości.

Propaganda tudjmanowskiej Chorwacji wzmacniała rolę mitów w bieżącym życiu wewnętrznym państwa, co budziło niesmak demokratycznych i liberalnych środowisk politycznych z państw Wspólnoty. Uznawano, że F. Tudjman szukał miejsca Chorwacji w UE, nie akceptując sporej części wartości, którymi kierowała się Wspólnota. Nie widział możliwości rozwijania wielostronnej współpracy regionalnej, niechętnie spoglądał nawet na kooperację w dziedzinie handlu i transportu. W jego przekonaniu, Chorwacja powinna przystąpić do UE bezpośrednio, bez konieczności przejmowania niejasnych reguł współpracy z innymi państwami postkomunistycznymi, zwłaszcza postjugosłowiańskimi. Jak podkreślał, Chorwaci należą do Europy i chcą wstąpić do Unii Europejskiej, ale z gwarancjami, że ich tożsamość nie będzie stłamszona.

${ }^{39}$ D. Jović, Croatia and the European Union, s. 98. 


\section{BIBLIOGRAFIA}

Agičić Damir, Historiografia chorwacka w latach 1990-2010. Struktura i główne kierunki rozwoju, „Prace Komisji Środkowoeuropejskiej PAU”, t. 20, 2012, s. 63-75.

Bartlett William, Croatia: between Europe and the Balkans, Routledge, London, 2002.

Belaj Marijana, Škrbić Alempijević Nevena, Remembering "The Father of the Contemporary State of Croatia". The Celebration of Tuđman's Birthday in His Birthplace, "Traditiones", t. 43, nr 1, 2014, s. $79-109$.

Bing Albert, Franjo Tuđman i samoodređenje naroda, w: Dr. Franjo Tuđman u okviru hrvatske historiografie, Vijoleta Herman-Kaurić (red.), Hrvatski institute za povijest, Zagreb, 2009, s. 79-89.

Bing Albert, Hrvatska u međunarodnoj zajednici, w: Stvaranje hrvatske države i Domovinski rat, Zdenko Radelić, Davor Marijan, Nikica Barić, Albert Bing, Dražen Živić, Školska knjiga, Hrvatski institut za povijest, Zagreb 2006, s. 290-420.

Bing Albert, Samoodreðenje naroda i koncepcije hrvatske državnosti u kontekstu Drugog svjetskog ratarefleksije povijesnog kontinuiteta, „RADOVI - Zavod za hrvatsku povijest”, t. 45, 2013, s. 129-154.

Czerwiński Zbigniew, Chorwacja między Europa a Batkanami. Analiza dyskursu prasowego, w: W poszukiwaniu nowego kanonu, Reinterpretacje tradycji kulturalnej w krajach postjugosłowiańskich po 1995 roku, Maria Dąbrowska-Partyka (red), Wydawnictwo Uniwersytetu Jagiellońskiego, Kraków, 2005, s. 97-117.

Đurasković Stevo, Nation-building in Franjo Tuđman's Political Writings, "Croatian Political Science Review", t. 51, nr 5, 2014, s. 58-79.

Fisher Sharon, Political change in post-Communist Slovakia and Croatia: From nationalist to Europeanist, Palgrave Macmillan, New York, 2006.

Hrvatska riječ svijetu. Razgovori sa stranim predstavcima, Anđelko Mijatović (red.), Svjedoci povijesti, Zagreb, 1999.

Jovic Dejan, Croatia and the European Union: a long delayed journey, "Journal of Southern Europe and the Balkans", t. 8, nr 1, 2006, s. 85-103.

Klepač Pogrmilović Bojana, Evaluating Tuđman's foreign policy. (Un)successful protection of national interest; from defender to despot, "Međunarodne studije", t. 13, nr 3-4, 2013, s. 55-79.

Kulić Slavko, Hrvatska kao srednjoeuropska i mediteranska kultura i civilizacija - jadranski prostor kao najkvalitetniji prostor Hrvatske, "Ekonomski pregled" t. 58, nr 3-4, 2007, s. 224-240.

Lindstrom Nicole, Between Europe and the Balkans: Mapping Slovenia and Croatia's "Return to Europe" in the 1990s, "Dialectical Anthropology", t. 27, 2003, s. 313-329.

Novosel Pavao, Europa 1992 i Hrvatska 1991, w: Novinarstvo i Europa 92, Mario Plenković (red.), Alinea, Zagreb, 1991.

Paszkiewicz Jędrzej, Exodus Serbów z Chorwacji i główne problemy związane z ich powrotem, w: EuropaPolska-migracja, Sebastian Wojciechowski, Radosław Fiedler (red.), Instytut Nauk Politycznych i Dziennikarstwa UAM, Poznań 2003, s.

Peskin Victor, International Justice in Rwanda and the Balkans, Cambridge University Press, Cambridge 2008.

Peskin Victor, Boduszynski Mieczysław, International justice and domestic politics: post-Tudjman Croatia and the International Criminal Tribunal for the Former Yugoslavia, "Europe-Asia Studies", t. 55, nr 7, 2003, s. 1117-1142.

Petrovic Milenko, The Democratic transition of post-communist Europe: in the shadow of communist differences and uneven EUropeanisation, Houndmills, New York, 2013.

Razsa Maple, Lindstrom Nicole, Balkan is beautiful: Balkanism in the political discourse of Tudman's Croatia, "East European Politics and Societies", t. 18, nr 4, 2004, s. 628-650.

Sadkovich James, Forging Consensus: How Franjo Tuđman became an authoritarian nationalist, "Review of Croatian History", t. 6, nr 1, 2010, s. 7-35. 
Sadkovich James. Franjo Tuđman: An intellectual in politics, w: Croatia since Independence: war, politics, society, foreign relations, Sabrina P. Ramet, Konrad Clewing, Reneo Lukić (red.), R. Oldenbourg Verlag, München, 2008, s. 59-85.

Sadkovich James, Tuđman: prva politička biografija, Večernji posebni proizvodi, Zagreb, 2010.

Sadkovich James, Franjo Tuđ̈man i problem stvaranja hrvatske države, "Časopis za suvremenu povijest", nr 1, 2008, s. 177.-195.

Senjković Reana, Olučni i nasmijani (vizualni aspekti političke propagande za izbora u Hrvatskoj: 1990.1997.), „Etnološka tribina”, t. 27, 1997, s. 95-132.

Skoko Božo, Percepcija Europske Unije u hrvatskoj javnosti, „Anali hrvatskog politološkog društva”, t. 3, nr 1, 2006, s. 349-368.

Subotic Jelena, Europe is a state of mind: identity and Europeanization in the Balkans, "International Studies Quarterly", t. 55, 2011, s. 309-330.

Tuðman Franjo, On historical necessity and contradictions between sovereignty and integration of European nations, „National security and the future”, t. 3-4, nr 1, 2000, s. 147-152.

Tuđman Franjo, Velike ideje i mali narodi. Razprave i ogledi, Matica hrvatska, Zagreb 1996.

Uzelac Gordana, 1998, Franjo Tudjman's Nationalist Ideology, "East European Quarterly", t. 31, nr 4, 1998, s. 449-472.

Źródło internetowe: http://www.tudjman.hr/govori/ 
